\title{
An Application of a Questionnaire of Social and Cultural Capital to English Language Learning
}

\author{
Reza Pishghadam (Corresponding author) \\ English Department, Ferdowsi University of Mashhad \\ PO box 91779-48974, Park Square, Ferdowsi University Mashhad, Iran \\ E-mail: rpishghadam@yahoo.com \\ Mohsen Noghani \\ Department of Sociology, Ferdowsi University of Mashhad \\ PO box 91779-48974, Park Square, Ferdowsi University Mashhad, Iran \\ E-mail: mohsennoghani@yahoo.com \\ Reza Zabihi \\ English Department, Ferdowsi University of Mashhad \\ PO box 91779-48974, Park Square, Ferdowsi University Mashhad, Iran \\ E-mail: zabihi@hotmail.com
}

Received: February 9, 2011 Accepted: March 8, 2011 doi:10.5539/elt.v4n3p151

\begin{abstract}
The aim of this study was to find out the relationship between EFL students' social as well as cultural capital and their foreign language achievement, using Bourdieu's theories in the sociology of education as frames of reference. To this end, the Social and Cultural Capital Questionnaire (SCCQ) was administered to 128 EFL learners majoring in English language. The Multiple Linear Regression Analysis was performed to analyze the data. Social and cultural capital data were matched with university students' academic records in language proficiency courses. Results indicated that cultural competence was the best predictor of the listening skill, whereas speaking, reading, writing, grammar, and the total GPA were mostly predicted by students' diploma GPA and literacy, the two factors which are related to cultural capital. Finally, statistical results were discussed, and implications were provided in the context of English language teaching.
\end{abstract}

Keywords: Bourdieu, Social capital, Cultural capital, Foreign language skills

\section{Introduction}

Learning never takes place in a vacuum. It occurs within a variety of contexts, some of which are more conducive to the process of cognitive, affective, and social development than others. The impact of context on learning a language is considerable, both at the macro level of the culture in which the learning takes place, and the micro level of school and family. According to Williams and Burden (1997), learning environments will enable individuals to learn how to learn and to develop as fully integrated learners. Learner's access to different cultural goods such as, Internet, computers, pictures, paintings, books, and dictionaries (Cultural capital), and learners' relationships with teachers, parents, siblings, and peers (Social capital) may have a profound influence upon whether, what and how any individual learns a language.

According to Bourdieu (1986), capital is not only economic but is also social and cultural. That is to say, society can also be structured by the differential distribution of cultural and social capital. These two types of capital can be powers that define the chances of profit in a given field. The more one possesses cultural and social capital, the more successful one may be in a specific area. Thus, these types of capital can be considered as guarantees of success.

In the area of education, there is a consensus among researchers on the importance of recognizing the structure of relations among social and educational institutions by examining how individuals' different social and cultural experiences affect their educational outcomes (Crosnoe, 2004; Kim \& Schneider, 2005; Prado, 2009; Schlee, Mullis, \& Shriner, 2009; Tramonte \& Willms, 2010). Since the early works on cultural capital in the 1980s and the works on social capital in the 1990s, a plethora of studies has been conducted to investigate the effects of these variables on different dimensions of academic achievement. For example, high school grades (DiMaggio, 1982), educational 
attainment (De Graaf, De Graaf, \& Kraaykamp, 2000; Merenluoto, 2009; Nakhaie \& Curtis, 1998; Sandefur, Meier, \& Hernandez, 1999), students' math scores (Bassani, 2006), student persistence (Wells, 2008), and educational achievement (Eng, 2009; Israel, Beaulieu, \& Hartless, 2001) have been found to be positively influenced by either social or cultural capital.

In the realm of language learning, Bourdieu's ideas mostly have been used to manifest the nexus between power and language (Kumaravadivelu, 2006; Norton \& Toohey, 2002). Bourdieu, Passeron, and Martin (1996) draw heavily on the relevance of social and cultural capital to language by claiming that the educational system tends to reinforce the social inequalities inherent in society by failing to consider the different amounts of cultural and linguistic competence possessed by different learners with different social class backgrounds. Therefore, Bourdieu (1977) adds an element of power to language competence, and maintains that language competence cannot be understood apart from social class. Grant and Wong (2008) make reference to Bourdieu's 'right to speak', and argue that it is important to pay attention to the differential treatments that language learners receive with respect to race, ethnicity, and social class (pp. 171-173). For example, as Bernstein (1996) argued, so many working-class children were failing in the British educational system because they grew up learning a restricted code which was not used at school, while middle-class children acquired the elaborated code which was used mostly in education. That is to say that, access to the elaborated code can give more power to the middle-class children, making them more successful in education. This is in line with Kumaravadivelu's claim (2006) that language can be used as an instrument of communication and control, and coercion as well as constraint.

Although the importance of Bourdieu's ideas in language learning have been highlighted by many authors (e.g., Clemente, 2007; Lin, 1999; Pennycook, 2001), no research has been conducted to date to operationalise social and cultural capital in the realm of sociology or Second/Foreign Language Learning (ESL/EFL). Therefore, we have attempted to examine the relationship between social as well as cultural capital and foreign language learning, making use of a previously-designed-and-validated social and cultural capital questionnaire, to shed more light on the use of the instrument in the second language learning research.

\section{Theoretical framework}

In the following paragraphs, we will review very briefly the notions related to cultural and social capital as well as empirical findings pertaining to these issues and their applications both in general education and language learning.

\subsection{Cultural and social capital in education}

Bourdieu (1986) maintains that cultural capital exists in three forms, namely, embodied state (long-lasting dispositions of body and mind), objectified state (cultural goods such as pictures, paintings, books, monuments, instruments, writings, machines, dictionaries, etc.), and institutionalized state (academic qualifications and degrees). He also defines social capital as "the aggregate of the actual or potential resources which are linked to possession of a durable network of more or less institutionalized relationships of mutual acquaintance and recognition." These relationships can exist in material and symbolic exchanges which might offer each of its members the "backing of the collectively-owned capital" (p. 248). Social capital might include: number of close friends, presence of two parents at home, number of siblings, extracurricular activities, church attendance, parent knowledge of children's friends, parents` employment, parent monitoring and involvement in education, etc.

Bourdieu (1993) proposed the ideas of cultural and social capital to break with the presupposition inherent in the commonsense view, which considers academic success and failure as an effect of natural aptitudes. According to him, mental abilities alone are not responsible for academic achievement; the types of capital learners bring to education can contribute to their academic achievement. Different social classes possess different amount of social and cultural capital. Those learners who possess more cultural goods and have access to more social network of friends and institutions can guarantee more success in education. Therefore, it is fair to say that children of families with more social and cultural capital are more successful in education, which might be "reproduced" in the successive generations of the children. Of course, this "reproduction" can lead to the transmission of social inequality in society, hindering the educational and life chances of poor families" children. There is a large body of empirical evidence suggesting links between cultural as well as social capital and different dimensions of academic success such as: educational achievement (Bassani, 2006; Crosnoe, 2004; DiMaggio, 1982; Eng, 2009; Israel \& Beaulieu, 2004; Israel, Beaulieu, \& Hartless, 2001), educational attainment (De Graaf, De Graaf, \& Kraaykamp, 2000; Merenluoto, 2009; Nakhaie \& Curtis, 1998; Sandefur, Meier, \& Hernandez, 1999), and student persistence (Kim \& Schneider, 2005; Wells, 2008). All of these studies espouse the idea that social and cultural capital are of paramount importance in education and worthy of consideration by researchers and practitioners.

\subsection{Cultural and social capital in language learning}

As it was already mentioned, the idea of the relationship between "power and capital" has been highlighted in Bourdieu's works $(1986 ; 1993)$. In the field of language learning, his ideas have been employed to show the 
relationship between power, language, identity, cultural and social capital (Kumaravadivelu, 2006). As Pennycook (2001, p. 120) points out, "a major task for critical applied linguistics is to find ways to meet the challenge of working across multiple levels, of looking at contextual issues of second language acquisition, while accounting for layers of institutional influence and relations of ethnicity, gender, or social class." In the same vein, Ricento (2005) has correctly pointed out that educational institutions play a critical role in production and reproduction of social identities and unequal relations of power in society.

One important issue which has been examined by researchers in the field of language learning is the relationship between social class, success and different capitals learners possess. For example, Clemente (2007) explains how ESL students show differing degrees of eagerness to learn English (linguistic capital) with respect to the amount of cultural capital they possess. She observed that while middle-class students consistently participated in and paid attention to classroom activities, working-class students did not seem to regard the English language to be that much necessary for their career, and consequently, they did not share a strong sense of accomplishment as middle-class students did.

Moreover, as Pavlenko (2002, p. 281) states, "The social context is directly involved in setting positive or negative conditions for L2 learning." This is in line with Bourdieu's (1986) reproductive standpoint by which he maintains that social inequalities among social classes are reproduced in the context of education. Lin (1999), however, elaborates on the importance of sociocultural and economic "situatedness" (p. 411), and maintains that different kinds of creative, discursive agency are needed on the part of ESL teachers for each particular classroom situation in order to transform, rather than reproduce, ESL learners' social worlds into more cooperative and attentive environments.

\subsection{Purpose of the present study}

As noted earlier, much research has been conducted on the relationship between social capital and academic achievement (e.g., Eng, 2009; Israel \& Beaulieu, 2004; Israel, Beaulieu, \& Hartless, 2001) and on the association between cultural capital and academic achievement (e.g., De Graaf, De Graaf, \& Kraaykamp, 2000; DiMaggio, 1982; Merenluoto, 2009). Moreover, research in the field of language learning has focused mostly on social inequality, cultural identity, social class, and language and power relationship (e.g., Pennycook, 2001; Ricento, 2005). Due to the importance of social and cultural capital concepts in language learning, this study intends to apply the social and cultural capital questionnaire to the language learning context in Iran. With that in mind, this study investigates two research questions:

Q 1: What are the best predictors of cultural capital in foreign language learning?

Q 2: What are the best predictors of social capital in foreign language learning?

\section{Method}

\subsection{Participants}

A sample of 128 people participated in this study, comprised of 86 females and 42 males between the ages of 19 and $33(\mathrm{M}=21.7, \mathrm{SD}=2.02)$. All of the participants were university students attending three universities in Iran, majoring in English Literature (54), English Teaching (48), and English Translation (25). They were all in their second year and passed their language proficiency courses including: Listening, Speaking, Reading, Writing, and Grammar.

\subsection{Instrumentation}

\subsubsection{The Social and Cultural Capital Questionnaire (SCCQ)}

Developed by Pishghadam, Noghani, and Zabihi (In press), the questionnaire was designed to measure students' social and cultural capital. It comprises 42 items measuring five subscales, namely, social competence, social solidarity, literacy, cultural competence, and extraversion that are scored on a 5-points Likert-scale. For the scoring of the Social and Cultural Capital Questionnaire we simply assign values 1,2,3, 4, and 5 to options strongly disagree, disagree, undecided, agree, and strongly agree, respectively. The reliability estimates for the five underlying factors of SCCQ are as follows: social competence, $r=.89$; social solidarity, $r=.75$; literacy, $r=.68$; cultural competence, $r$ $=.65$; extraversion, $\mathrm{r}=.51$. The reliability of the whole items is 0.88 .

\subsection{Procedures}

The questionnaire comprises 42 items which are measured with the use of two subscales: Social capital and Cultural capital. The items are scored according to the five-points Likert-scale ranging from (1) "strongly disagree" to (5) "strongly agree". Besides, students' were asked to provide answers to questions regarding family income, parents' educational level, and their diploma grade point average (GPA). The questionnaire was distributed among $128 \mathrm{EFL}$ students from three universities of Mashhad in Iran. The questionnaire was administered to them and they were asked to fill out the questionnaire. To meet the aim of the study, in addition to the data gathered through this 
questionnaire, the participants' scores in their language proficiency courses including: Listening, Speaking, Reading, Writing, Grammar, and the grade point average (GPA) pertaining to these courses were obtained.

Having administered the questionnaire to EFL students, the researchers processed the data with SPSS 16 program. Social and cultural capital data were matched with the students' academic records in language proficiency courses, at university at the end of second year. We used the Multiple Regression Analysis with a Stepwise Method to detect the best predictors in foreign language achievement in terms of social and cultural capital scores.

\section{Results}

A Multiple Regression Analysis was conducted to examine to what extent social capital, cultural capital, parents' education level, family income, and diploma GPA predict six dimensions of foreign language achievement, namely, listening, speaking, reading, writing, grammar, and second-year university grade point average (GPA).

Table 1 presents the results for language proficiency course grades being regressed on the variables of interest in this study. The results reveal which variables are important in predicting foreign language achievement.

As may be seen in Table 1, the listening skill explained $13 \%$ of the total variance, $\left(\mathrm{R}^{2}=.13, \mathrm{p}<.05\right)$ using a combination of cultural competence and social solidarity. Having high levels of cultural competence and social solidarity was the best predictor of high scores in the listening skill.

The speaking skill had $21 \%$ of the total variance, $\left(\mathrm{R}^{2}=.21, \mathrm{p}<.05\right)$ using a combination of literacy, diploma GPA, and cultural competence. Having high levels of literacy, diploma GPA, and cultural competence was the best predictor of high scores in the speaking skill.

The reading skill had $15 \%$ of the total variance, $\left(\mathrm{R}^{2}=.15, \mathrm{p}<.05\right)$ with the diploma GPA and literacy as the only variables which entered the regression model. Having high levels of diploma GPA and literacy was the best predictor of high scores in the reading skill.

The writing skill accounted for $22 \%$ of the total variance, $\left(\mathrm{R}^{2}=.22, \mathrm{p}<.05\right)$ using a combination of diploma GPA and literacy. High levels of diploma GPA and literacy were the best predictors of high scores in the writing skill.

The grammar dimension of the English language achievement had $31 \%$ of the total variance, $\left(\mathrm{R}^{2}=.31, \mathrm{p}<.05\right)$ with diploma GPA and literacy as the only variables which entered the regression model. Having high levels of diploma GPA and literacy was the best predictor of high scores in the grammar course.

Finally, The GPA for language proficiency course grades had $41 \%$ of the total variance, $\left(\mathrm{R}^{2}=.41, \mathrm{p}<.05\right)$ using a combination of diploma GPA and literacy. High levels of diploma GPA and literacy were the best predictors of high scores in the total GPA.

\section{Discussion}

As mentioned earlier, there is a high association between social and cultural capital and academic achievement. It means that those who have more access to these two types of capital are more successful in educational attainment (De Graaf, De Graaf, \& Kraaykamp, 2000; Kim \& Schneider, 2005; Prado, 2009). With that in mind, we have attempted to examine the relationship between social and cultural capital and foreign language learning in order that we might widen and enrich our understanding of this relationship and also shed more light on the nature of foreign language learning.

Our results suggest that cultural competence is the best predictor of the listening and speaking skills. This means that those who attend music classes, theatres, and concerts more frequently are more successful in the listening and speaking skills. All of these cultural recourses and activities are generally in association with oral aspect of language and, thus, they set the scene for learning the listening and speaking skills. This finding is similar to that obtained by Nino (2010) who concluded that music improved foreign language learners' oral performance. Moreover, social solidarity was another factor in predicting listening in a foreign language. That is, those who establish more strong ties with other people in the society are more successful in the listening skill. This finding is in line with Sociocultural Theory which views social interaction as facilitative of acquisition and the site where acquisition takes place (Ellis \& Fotos, 1999, p. 246).

On the other hand, Speaking, Reading, Writing, Grammar, and the total GPA are mostly predicted by students' diploma GPA and literacy. As we have already mentioned, academic qualifications and degrees constitute a subscale of cultural capital under the rubric institutionalized cultural capital. Unlike other measures of cultural capital which are largely being provided by family, this type of cultural capital is mostly under the influence of the school setting. Therefore, the prediction of these four dimensions of foreign language achievement (speaking, reading, writing, and grammar) by students' diploma GPA may be due to the predominant role of the educational system in providing schools and universities with the necessary educational capital which helps students speak, read and write efficiently 
and grammatically. This finding is quite in line with Bourdieu's emphasis on the important role of school as the second source of providing and appropriating cultural capital (Bourdieu \& Johnson, 1993).

Likewise, literacy was found to be a highly significant factor in explaining foreign language achievement. Literacy is regarded as a social practice (McKay \& Hornberger, 1996, p. 438) and it is not only achieved by individuals, but also it can be obtained in schools, in families (family literacy), in the workplace, etc. (Kern, 2000, p. 24). This finding supports Linguistic Coding Differences Hypothesis in which Sparks and Ganschow (1999) claim that one's capacity to learn L2 is related to L1 learning skills. According to this hypothesis, L2 learning difficulties stem in part from L1 literacy skills difficulties. Therefore, it is right to conclude that teachers should go beyond L2 language learning classrooms, entering into the realm of L1 literacy skills to solve the learners' language learning problems.

In the discussions of language learning failures, the focus of attention is mostly directed at the academic environments. As a result, every effort is made to promote the curriculum, course requirements, measurement procedures, as well as to hire more qualified language teachers and to expand funding. Our results suggest, however, that another factor that has a significant effect on students' achievement of the English language is what happens in the home environment, with family as the first provider of cultural resources. The same conclusion can be better drawn from the words of Jager and Holm (2007, p. 723) who consider the home environment as a "learning lab". What we need to do is to design a set of strategies for creating a richer and more nurturing environment in the home. Nurturing practices such as reading to children in English, watching English cartoons or movies, and holding discussions with them on how they can best handle another language may be useful. Such activities, however, require that parents themselves have at least a general know-how of the English language.

In the context of English language teaching profession, our results continue to demonstrate the important role that English language teachers play in nurturing EFL students. English teachers are expected to be familiar with the cultural goods and resources such as different books and dictionaries, multi-purpose audio and visual softwares, striving hard to enhance the cultural capital of their own learners. To this end, however, they themselves should try to improve their own cultural capital first. It seems to be natural that an English teacher with a low level of cultural capital and the one who has little knowledge about the best cultural resources necessary for learning English may not satisfy the students' needs, and so he will be of little help to them.

These results are expected to be more investigated by other researchers. Therefore, we recommend that SLA research go deep into these sociological variables. A replication of this study with a large sample in another context can help us to have a solid understanding of the relationship between social and cultural capital and foreign language achievement.

In the end, researchers are recommended to examine objectively the relationship between social and cultural capital and other related variables such as: literacy, motivation, social division, or identity formation. These variables seem to be highly related to social and cultural factors. Finding any association between these variables and social and cultural capital helps us have a better understanding of the role of these socio-cultural factors in second language learning research.

\section{References}

Bassani, C. (2006). A test of social capital theory outside of the American context: Family and school social capital and youths' math scores in Canada, Japan, and the United States. International Journal of Educational Research, 45(6), 380-403. doi:10.1016/j.ijer.2007.03.001, http://dx.doi.org/10.1016/j.ijer.2007.03.001

Bernstein, B. (1996). Pedagogy, symbolic control, and identity: Theory, research, critique. London: Taylor and Francis.

Bourdieu, P. (1977). The economics of linguistic exchanges. Social Science Information, 16, 645-668. doi:10.1177/053901847701600601, http://dx.doi.org/10.1177/053901847701600601

Bourdieu, P. (1986). The forms of capital. In: J. G. Richardson (ed.), Handbook for theory and research for the sociology of education (pp. 241-258). New York: Greenwood Press.

Bourdieu, P., \& Johnson, R. (1993). The field of cultural production: Essays on art and literature. New York: Columbia University Press.

Bourdieu, P., Passeron, J., \& Martin, M.S. (1996). Academic discourse: Linguistic misunderstanding and professorial power. California: Stanford University Press.

Clemente, A. (2007). English as cultural capital in the Oaxacan community of Mexico. TESOL Quarterly, 41 (2), 421-426. 
Crosnoe, R. (2004). Social capital and the interplay of families and schools. Journal of Marriage and Family, 66, 267-280. doi:10.1111/j.1741-3737.2004.00019.x, http://dx.doi.org/10.1111/j.1741-3737.2004.00019.x

De Graaf, N. D., De Graaf, P. M., \& Kraaykamp, G. (2000). Parental cultural capital and educational attainment in the Netherlands: A refinement of the cultural capital perspective. Sociology of Education, 73(2), 92-111. doi:10.2307/2673239, http://dx.doi.org/10.2307/2673239

DiMaggio, P. (1982). Cultural capital and school success: The impact of status culture participation on the grades of U.S. high school students. American Sociological Review, 47, 189-201. doi:10.2307/2094962, http://dx.doi.org/10.2307/2094962

Ellis, R., \& Fotos, S. (1999). Learning a Second Language through Interaction. Amsterdam: John Benjamins Publishing Company.

Eng, S. (2009). Social capital and academic achievement among children in Cambodia: A close look at family. Doctoral dissertation. Texas Tech University, Texas.

Gass, S.M., \& Selinker, L. (2001). Second language acquisition: An introductory course. Mahwah, NJ: Lawrence Erlbaum Associates.

Grant, R.A., \& Wong, S.D. (2008). Critical race perspectives, Bourdieu, and language education. In: J., Albright, \& A., Luke (Eds.), Pierre Bourdieu and literacy education (pp. 162-184). London: Routledge.

Israel, G. D., \& Beaulieu, L. J. (2004). Investing in communities: Social capital's role in keeping youth in school. Journal of the Community Development Society, 34, 35-57. doi:10.1080/15575330409490111, http://dx.doi.org/10.1080/15575330409490111

Israel, G. D., Beaulieu, L. J., \& Hartless, G. (2001). The influence of family and community social capital on educational achievement. Rural Sociology, 66, 43-68. doi:10.1111/j.1549-0831.2001.tb00054.x, http://dx.doi.org/10.1111/j.1549-0831.2001.tb00054.x

Jager, M. M., \& Holm, A. (2007). Does parents' economic, cultural, and social capital explain the social class effect on educational attainment in the Scandinavian mobility regime? Social Science Research, 36, 719-744. doi:10.1016/j.ssresearch.2006.11.003, http://dx.doi.org/10.1016/j.ssresearch.2006.11.003

Kern, R. (2000). Literacy and language teaching. Oxford: Oxford University Press.

Kim, D. H., \& Schneider, B. (2005). Social capital in action: Alignment of parental support in adolescents' transition to postsecondary education. Social Forces, 84, 1181-1206. doi:10.1353/sof.2006.0012, http://dx.doi.org/10.1353/sof.2006.0012

Kumaravadivelu, B. (2006). Understanding language teaching: From method to postmethod. Laurence Erlbaum Associates, Publishers.

Lin, A.M.Y. (1999). Doing-English-lessons in the reproduction or transformation of social worlds? TESOL Quarterly, 33(3), 393-412. doi:10.2307/3587671, http://dx.doi.org/10.2307/3587671

McKay, S. L. (1996). Literacy and literacies. In S. L. McKay \& N. H. Hornberger (Eds.), Sociolinguistics and language teaching. (pp. 421-445). Cambridge: Cambridge University Press.

Merenluoto, S. (2009). The connection of cultural capital with success in master's degree programs in Finnish higher education. Research on Finnish Society, 2, 29-38.

Nakhaie, M. R., \& Curtis, J. (1998). Effects of class positions of parents on educational attainment of daughters and sons. The Canadian Review of Sociology and Anthropology, 35(4), 483-515. doi:10.1111/j.1755-618X.1998.tb00733.x, http://dx.doi.org/10.1111/j.1755-618X.1998.tb00733.x

Nino, P. (2010). The role of music in young learners' oral production in English. Profile, 12 (1), 141-157.

Norton, B., \& Toohey, K. (2002). Identity and language learning. In R.B., Kaplan (Ed.), The Oxford handbook of applied linguistics (pp. 115-123). Oxford: Oxford University Press.

Pavlenko, A. (2002). Poststructuralist approaches to the study of social factors in L2. In: V. Cook (Ed.), Portraits of the L2 User. (pp. 277-302). Clevedon: Multilingual Matters.

Pennycook, A. (2001). Critical applied linguistics. Mahwah, NJ: Lawrence Erlbaum Associates.

Pishghadam, R., Noghani, M., \& Zabihi, R. (In press). The construct validation of a questionnaire of social and cultural capital. English Language Teaching.

Prado, J. M. (2009). Comparing educational trajectories of two Chinese students and one Latina student, a social 
capital approach. The High School Journal, 92, 14-27. doi:10.1353/hsj.0.0015, http://dx.doi.org/10.1353/hsj.0.0015 Ricento, T. (2005). Considerations of identity in L2 learning. In E. Hinkel (ed.), Handbook of research in second language teaching and learning. (pp. 895-910). Lawrence Erlbaum Associates, Publishers.

Sandefur, G., Meier, A., \& Hernandez, P. (1999). Families, social capital and educational continuation. CDE Working Paper No. 99-19: Center for Demography and Ecology. Madison, WI: University of Wisconsin-Madison.

Schlee, B. M., Mullis, A. K., \& Shriner, M. (2009). Parents social and resource capital: Predictors of academic achievement during early childhood. Children and Youth Services Review, 31, 227-234. doi:10.1016/j.childyouth.2008.07.014, http://dx.doi.org/10.1016/j.childyouth.2008.07.014

Sparks, R.L., \& Ganschow, L. (1999). Native language skills, foreign language aptitude and anxiety about foreign language learning. In D.J., Young (ed.), Affect in foreign language and second language learning (pp. 169-190). Boston: McGraw-Hill.

Tramonte, L., \& Willms, J. D. (2010). Cultural capital and its effects on education outcomes. Economics of Education Review, 29, 200-213. doi:10.1016/j.econedurev.2009.06.003, http://dx.doi.org/10.1016/j.econedurev.2009.06.003

Wells, R. (2008). The effects of social and cultural capital on student persistence. Community College Review, 36, 25-46. doi:10.1177/0091552108319604, http://dx.doi.org/10.1177/0091552108319604

Williams, M., \& Burden, R.L. (1997). Psychology for language teachers: A social constructivist approach. Cambridge: Cambridge University Press.

Table 1. Multiple regression analyses predicting foreign language achievement

\begin{tabular}{lcccccc}
\hline Predictors & $\mathbf{R}$ & $\mathbf{R}^{\mathbf{2}}$ & Adjusted $\mathbf{R}^{\mathbf{2}}$ & $\mathbf{F}$ & $\mathbf{P}$ & $\boldsymbol{B}$ \\
\hline Listening & & & & & & \\
1. Cultural competence & 0.321 & 0.103 & 0.094 & 11.940 & 0.00 & 0.289 \\
2. Social solidarity & 0.373 & 0.139 & 0.123 & 8.337 & 0.04 & 0.193 \\
Speaking & & & & & & \\
1. Literacy & 0.348 & 0.121 & 0.113 & 14.492 & 0.01 & 0.245 \\
2. Diploma GPA & 0.428 & 0.183 & 0.167 & 11.656 & 0.00 & 0.270 \\
3. Cultural competence & 0.464 & 0.215 & 0.192 & 9.416 & 0.04 & 0.192 \\
Reading & & & & & & \\
1. Diploma GPA & 0.338 & 0.114 & 0.106 & 13.566 & 0.00 & 0.311 \\
2. Literacy & 0.389 & 0.151 & 0.135 & 9.246 & 0.03 & 0.193 \\
Writing & & & & & & \\
1. Diploma GPA & 0.424 & 0.180 & 0.172 & 22.588 & 0.00 & 0.392 \\
2. Literacy & 0.473 & 0.223 & 0.208 & 14.675 & 0.01 & 0.211 \\
Grammar & & & & & & \\
1. Diploma GPA & 0.516 & 0.266 & 0.259 & 37.414 & 0.00 & 0.489 \\
2. Literacy & 0.556 & 0.310 & 0.296 & 22.875 & 0.01 & 0.210 \\
GPA & & & & & & \\
1. Diploma GPA & 0.560 & 0.313 & 0.307 & 47.479 & 0.00 & 0.516 \\
2. Literacy & 0.643 & 0.413 & 0.402 & 36.248 & 0.00 & 0.319 \\
\hline
\end{tabular}

